\title{
CHAGAS DISEASE IN THE BRAZILIAN AMAZON. IV. A NEW CROSS-SECTIONAL STUDY
}

\author{
José Rodrigues COURA(1), Angela Cristina Veríssimo JUNQUEIRA(1), Marcio Neves BÓIA(1,2), Octavio FERNANDES(1,2), Claudina BONFANTE(3), \\ José Eduardo CAMPOS(3), Lucilaide SANTOS(3) \& Rodolfo DEVERA(3)
}

\begin{abstract}
SUMMARY
A new conglomerate family sample of 194 dwellings with 996 resident persons were studied in the town of Barcelos, State of Amazonas, in order to re-evaluate the risk of Chagas disease. During the survey the persons were interviewed and in this occasion we showed to them a collection of Panstrongylus, Rhodnius and Triatoma, asking if they recognized and eventually have been bitten by this kind of bugs. At this time we collected 500 ul of blood in microtainer ${ }^{\circledR}$ tubes from 886 interviewed persons who gave permission after informed consent. A screening test for T. cruzi antibodies based on agglutination of colored polymer particles, sensitized with three different synthetic peptides of $T$. cruzi (ID-PaGIA Chagas Test ${ }^{\circledR}$, showed $13.2 \%$ of sera positivity, but only $6.8 \%$ were confirmed by indirect immunofluorescence, and ELISA with purified T. cruzi antigens. Two hundred and six interviewed persons (20.7\%) recognized the triatomines, as "piaçavas' lice" and $62(30 \%)$ confirmed that have been bitten by the bugs, $25.8 \%$ of them had a positive serology for T. cruzi infection. Electrocardiographic alterations were shown in $9.3 \%$ of the seropositives and in $11.9 \%$ of the seronegative cases. This was considered not statistically significant.
\end{abstract}

KEYWORDS: Chagas Disease; Brazilian Amazon; Cross-sectional Study.

\section{INTRODUCTION}

Chagas disease has always been considered a sylvatic enzootic in Brazilian Amazon, until the first human cases were described, in $1969^{49}$. Since then, a number of human cases have been reported as consequence of microepidemics, isolated cases or described through serological

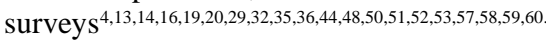

Since Carlos Chagas ${ }^{11}$ has confirmed as Trypanosoma cruzi, the parasites isolated from Saimiri sciureus by Aben-Athar, many reservoirs of the parasite were described in the Amazonian region $^{6,7,21,22,23,24,25,26,33,37,47,61}$. On the other hand, at least 16 species of triatomines, 10 of which infected with $T$. cruzi, were identified on that region ${ }^{1,2,5,7,8,27,38,39,40,41,42,43,46,55,61}$.

The risks of endemization of Chagas disease in the Amazonian region are related to deforestation and to the possible adaptation of sylvatic triatomines to human dwellings; or, yet, to the transposition of the domestic cycle from endemic areas to the Amazonian region, due to migration of infected people and/or to the carriage of vectors and domestic reservoirs from the endemic areas to that region $3,7,12,17,18,34,55$.

A national serological survey about the prevalence of Chagasic infection, accomplished by SUCAM, today Fundação Nacional de Saúde (National Health Foundation), from 1975 to 1980, indicated a prevalence of $1.88 \%$ in the State of Amazonas ${ }^{10}$, with a concentration of $6.3-6.8 \%$ in areas of Rio Negro ${ }^{51}$. In 1977, six autochthonous cases sera positive were registered in Barcelos ${ }^{32}$ and, in 1985, one acute case of combined infection by $T$. cruzi and $T$. rangeli was described in the same region ${ }^{53}$.

From 1991 on, we have accomplished various serological surveys and sectional studies in the town of Barcelos and among the riverside population of Rio Negro and its affluents Aracá, Curudurí, Padaurí and Preto. These studies have revealed a high serological prevalence of Chagasic infection, PCR positiveness and isolation of T. cruzi and T. rangeli, particularly among workers of piaçava's gathering and their families, as well as among sylvatic reservoirs and vectors of the region $^{13,14,15,16,17,19}$.

The present study re-evaluates the prevalence of Chagasic infection within a sample of residents in the town of Barcelos, in middle Rio Negro. It was used a new technique of polymer particles agglutination, sensitized by three different $T$. cruzi peptides (ID-PaGIA Chagas Test $\left.{ }^{\circledR}\right)^{45}$, as a screening test, and its confirmation by indirect immunofluorescence and ELISA reactions, with purified $T$. cruzi antigens from Biomanguinhos, Fiocruz. The study evaluates the risks of Chagasic infection transmission through the contact of the population with sylvatic triatomines, as well as disease morbidity, through comparison of electrocardiograms of sera positive and sera negative individuals for infection by Trypanosoma cruzi.

(1) Instituto Oswaldo Cruz (Fiocruz), RJ, Brasil.

(2) Universidade Estadual do Rio de Janeiro (UERJ), RJ, Brasil.

(3) Post graduate Medical Students, Instituto Oswaldo Cruz (Fiocruz), RJ, Brazil.

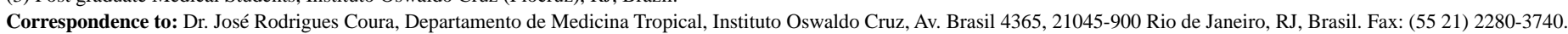
E-mail: coura@ioc.fiocruz.br 
In this article was evaluated the specificity of the ID-PaGIA Chagas Test $^{\circledR}$ for field work in the Amazon conditions, where the serology is usually complex, due to the possibility of cross reactions with other infections. On the other hand complementing our previous descriptive works ${ }^{14,19}$ was carried-out a cross sectional controlled clinical and epidemiological study to evaluate the risk factors for Chagas disease in the area, amplifying the sample.

\section{MATERIALS AND METHODS}

Area localization: The administrative center of the district of Barcelos is located on the right riverside of middle Rio Negro, 304 miles away from Manaus, capital of the state of Amazonas, considering fluvial way. The district is situated in the microregion of Rio Negro, north of the state; it limits in east with the state of Roraima, in south and southeast with the district of Novo Airão and Marãa, in west with the district of Santa Izabel and in north with Venezuela $\left(0^{\circ} 58^{\prime} 1\right.$ " south equatorial latitude and $62^{\circ} 56^{\prime}$ west Greenwich longitude) (Fig.1).

Sample and kind of study: It was made a cross sectional study with a systematic conglomerate family sample, considering one of each four inhabited dwellings of the town of Barcelos; what represented nearly $25 \%$ of the town's resident population. Schools, churches, public and commercial buildings were not considered for the study.

At first, a survey was made in order to register the number of inhabited dwellings and inhabitants of the six Barcelos' town districts. The town was distributed according to population concentration degree: Centro, São Francisco, São Lázaro, São Sebastião, Aparecida and Nazaré.

Then, in a more systematic way, each sample dwelling was visited by two doctors, who explained the objectives of the study to the family and obtained their permission for the survey.

Material and information collection: Two questionnaires were applied, one for the dwelling and the other for each individual, in order to analyze the population epidemiological and previous clinical conditions. The first questionnaire, directed to the family leader or, in his absence, to any member of the family able to answer it, had the objective to evaluate the physical and sanitary conditions of the dwelling: water supply, waste and sewage disposal, lightening and material goods, what indicates the economical level of the family. The individual questionnaire was directed to all family members (if there were minor children, the parents answered for them) and was constituted by an anamnesis about previous conditions, specially those related to risk factors for Chagasic infection, as: occupation, recognition of triatomines, possibility of having been bitten by the bugs, previous history of surgery and blood transfusion. Everyone was shown a collection of triatomines, formed by Pantrongylus, Rhodnius and Triatoma exemplars, and asked if they were able to recognize the bugs.

From every interviewed person over two years old, at the time of the first visit or later, it was collected $500 \mathrm{ul}$ of blood by finger puncture, into Microtainer ${ }^{\circledR}$ tubes (Beckton Dickson) ${ }^{\circledR}$ with sera separator gel, for serological reactions.

Laboratory procedures: The blood collected into the Microtainer ${ }^{\circledR}$ was centrifuged in $500 \mathrm{G}$, for 10 minutes; after that, $25 \mathrm{ul}$ of serum was extracted and transferred, through an automatic pipette with an individual point for each serum, to one of the six microtubes of the ID Chagas Test kit, with the red colored polymer particles, sensitized with three different synthetic peptides of $T$. cruzi antigens, previously homogenized. The combination of the serum and the polymer particles was incubated at room temperature, for 15 minutes; then, it was centrifuged in a special equipment for the kit, for 15 minutes more, according to the fabricant instructions. For each group, it was added a control serum positive, and another one, negative. In the positive considered sera, it was formed a red line on the top, as consequence of the adherence occurred between the particles and the antibodies; in the negative ones, a precipitate was formed on the microtube's bottom, after the centrifugation (Fig. 2). The sera considered positive, according to this technique, and a sample of the negative ones were tested afterwards by the indirect immunofluorescence reaction and by ELISA with purified soluble antigens,
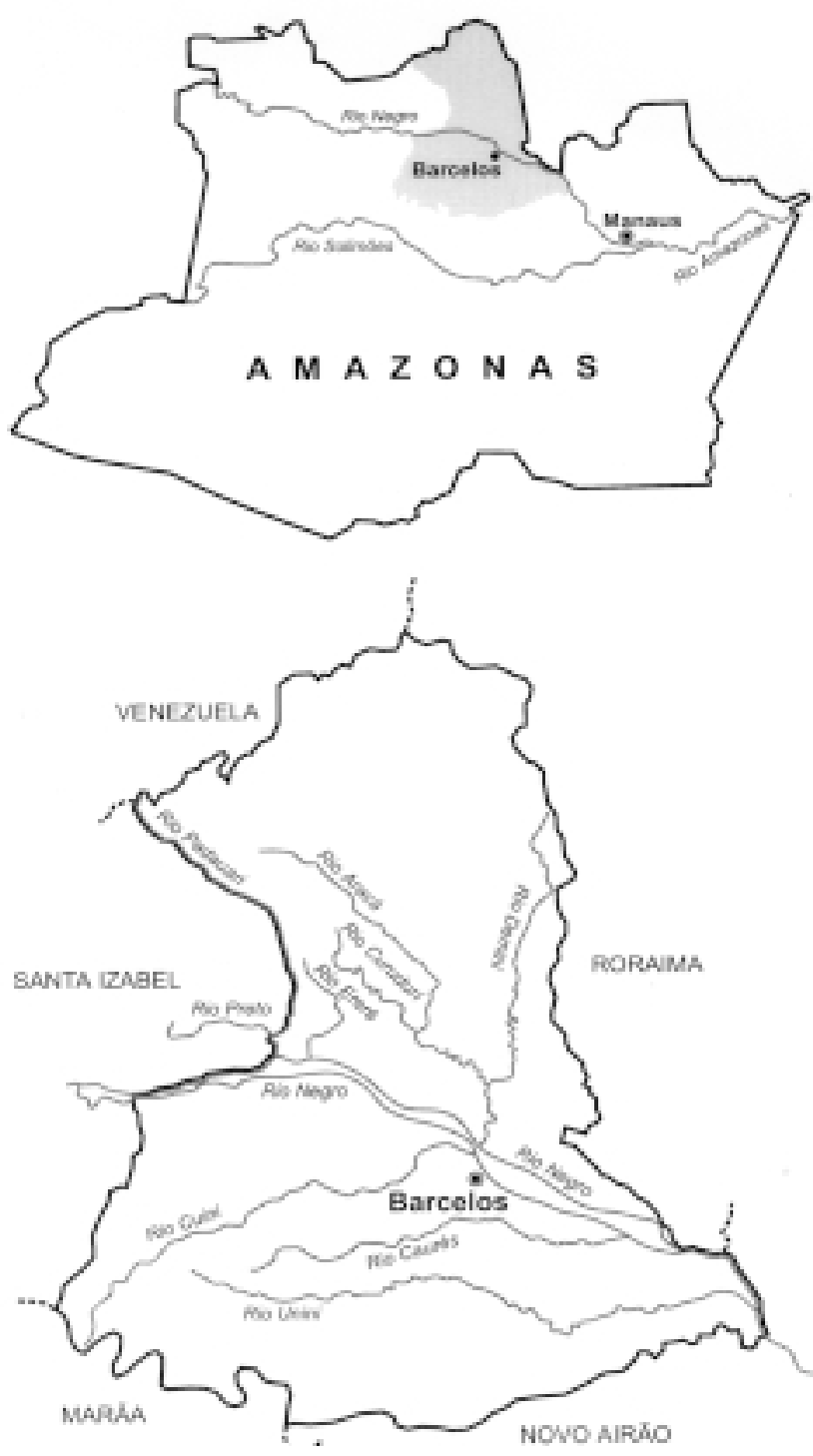

Fig. 1 - District of Barcelos in the microregion of Rio Negro, State of Amazonas 


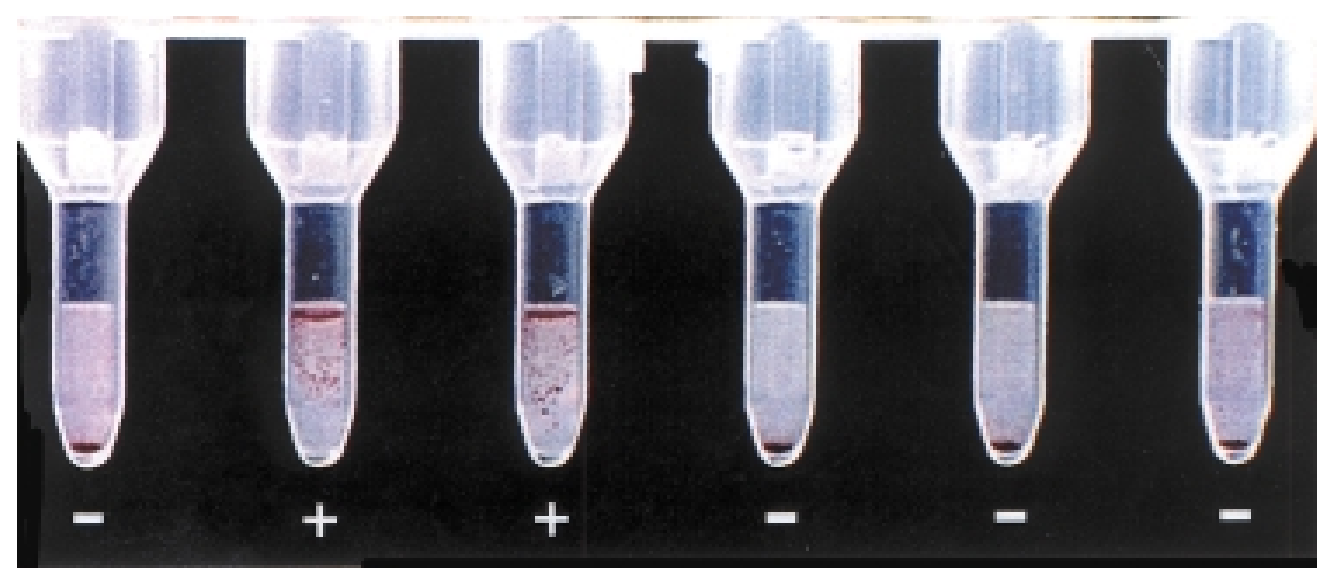

Fig. 2 - ID - PaGIA Chagas Test kit with positive and negative reactions

obtained through the culture of $T$. cruzi, produced by Biomanguinhos (Fiocruz).

Clinical and epidemiological procedures: Individuals with positive serology according to the screening method (ID-PaGIA Chagas Test) were paired with others of the same age and sex. On a second home visit, the 886 patients submitted to the screening test received the serological results and the 117 pairs (positive and negative) were invited to go to the local hospital, to be submitted to clinical and electrocardiographic exams, by the authors; also, their blood were collected through venous puncture in a vacutainer tube for confirming serological exam (by indirect immunofluorescence and ELISA with purified T. cruzi antigens), hemoculture, indirect xenodiagnosis and PCR, since the patients agreed with exams and blood collection, after informed consent.

\section{RESULTS}

Sample and population characteristics: The conglomerate family sample was constituted of 194 dwellings, where lived 996 persons: an average of 5.1 inhabitants for each dwelling. There were 442 (44.4\%) males and $554(55.6 \%)$ females. The distribution by age and sex (Table 1) shows that $56 \%$ of population are under 20 years old. Most of them are crosbred (caboclos), $30.5 \%$ are white and only $0.2 \%$ are black.

\section{Table 1}

Distribution by age group and sex of population sample from Barcelos, State of Amazonas

\begin{tabular}{ccccc}
\hline & \multicolumn{2}{c}{ Sex } & \multicolumn{2}{c}{ Total } \\
$\begin{array}{c}\text { Age group } \\
\text { (years) }\end{array}$ & $\begin{array}{c}\text { Female } \\
(\mathrm{N})\end{array}$ & $\begin{array}{c}\text { Male } \\
(\mathrm{N})\end{array}$ & $(\mathrm{N})$ & $(\%)$ \\
\hline $0-10$ & 154 & 136 & 290 & 29.1 \\
$11-20$ & 146 & 121 & 267 & 26.8 \\
$21-30$ & 84 & 62 & 146 & 14.7 \\
$31-40$ & 66 & 40 & 106 & 10.6 \\
$41-50$ & 45 & 29 & 74 & 7.4 \\
$51-60$ & 27 & 18 & 45 & 4.5 \\
$>60$ & 32 & 36 & 68 & 6.8 \\
\hline Total & $\mathbf{5 5 4}$ & $\mathbf{4 4 2}$ & $\mathbf{9 9 6}$ & $\mathbf{1 0 0 . 0}$ \\
\hline
\end{tabular}

The occupational analysis indicates that $33.4 \%$ were students, $17.4 \%$ worked at home and $13.3 \%$ were under five years old. Among the economical active population, commerce was the main activity $(4.7 \%)$, followed by domestic work (3.9\%), agriculture (2.8\%), teaching $(2.1 \%)$, public service $(2.1 \%)$, extracting $(2 \%)$ and fishing $(1.9 \%)$; only $2.5 \%$ were retired; $8.6 \%$ had various activities and $5.3 \%$ had no defined occupation.

Risk factors for Chagas disease: During the individual questionnaires, people were shown a collection of triatomines and 206 individuals $(20.7 \%)$ recognized at least one of the bug species. Most of them $(67.5 \%)$ saw the bugs at piaçava's palm trees; $36.4 \%$ of these worked on the extractive process of piaçava (Leopoldinia piassaba) and the others were the workers' family members or companions (Fig. 3). Among the triatomines, the Rhodnius was mostly identified $(60.7 \%)$. From the 206 individuals who identified the triatomine, 62 (30\%) told that had already been bitten by the bug, mostly in a piaçava's growing area. Among the individuals bitten by the bug, $25.8 \%$ had positive serology for $T$. cruzi infection, while among the ones who had not been bitten, only $11.7 \%$ had positive serology $(\mathrm{p}=0.03)$; what indicates a positive association between contact with triatomine and positive serology.

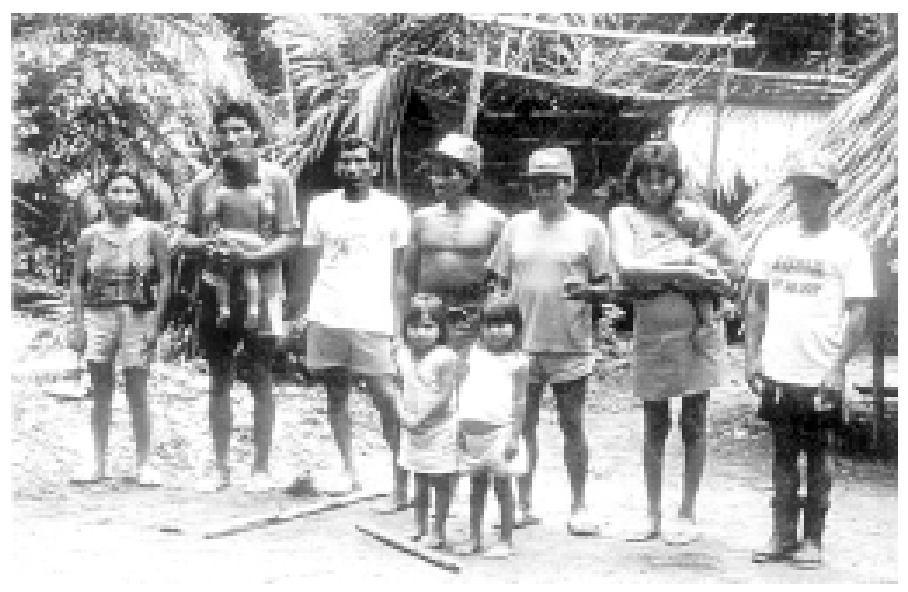

Fig. 3 - Piaçavas' workers and their families outside the huts in the work place 


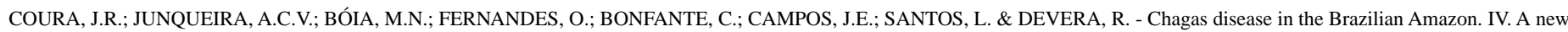
cross-sectional study. Rev. Inst. Med. trop. S. Paulo, 44(3):159-165, 2002.

Table 2

Serologic screening test with ID - PaGIA Chagas Test and \% of confirmed by IF + ELISA. Barcelos, State of Amazonas

\begin{tabular}{|c|c|c|c|c|c|}
\hline $\begin{array}{c}\text { Age group } \\
\text { (years) }\end{array}$ & $\begin{array}{l}\text { Total e } \\
\quad(N)\end{array}$ & $\begin{array}{c}\text { amined } \\
(\%)\end{array}$ & $\begin{array}{c}\text { ID-PaGIA } \\
(\mathrm{N})\end{array}$ & $\begin{array}{c}\text { Positives } \\
(\%)\end{array}$ & $\begin{array}{c}\% \text { Confirmed } \\
I F+E L I S A\end{array}$ \\
\hline$>2-10$ & 146 & 16.5 & 18 & 10.6 & 5.5 \\
\hline $11-20$ & 255 & 25.4 & 41 & 16.1 & 7.3 \\
\hline $21-30$ & 139 & 15.7 & 28 & 20.1 & 7.1 \\
\hline $31-40$ & 100 & 11.3 & 15 & 15.0 & 6.6 \\
\hline $41-50$ & 69 & 7.88 & 4 & 5.8 & - \\
\hline $51-60$ & 43 & 4.9 & 5 & 11.6 & 20.0 \\
\hline$>60$ & 65 & 7.4 & 6 & 9.2 & 16.6 \\
\hline Total & 886 & 100.0 & 117 & $13.2(*)$ & 6.8 \\
\hline
\end{tabular}

(*) Not excluded cross-reations. Only $6.8 \%$ were confirmed by indirect immunofluorescence (IF) and ELISA.

Considering all interviewed individuals, 86 had been submitted to a surgery; 19 of them $(2.2 \%)$ received blood transfusion during the surgery and 15 received blood transfusion for other reasons, what sums 34 individuals who received blood for some reason. In this case, there were no association between blood transfusion and positive serology.

From the 886 persons considered in the sample who agreed with blood collection for serological exam, 117 (13.2\%) were positive, according to the ID-PaGIA Chagas Test trial (Table 2); however, only $6.8 \%$ were confirmed, by indirect immunofluorescence and ELISA; from 92 sera negative by ID-PaGIA Chagas Test, 4 (4.3\%) were positive, by indirect immunofluorescence and ELISA, showing a low specificity of ID-PaGIA Chagas Test for T. cruzi antibodies for this lot of sera from Amazonas.

Ninety five percent of the population sample were autochthonous from the Amazonas State and 80\% from the Rio Negro area. Only 5\% were from other states and none of them had positive serology for Chagas infection; there was no difference or city clusters in relation to seropositivity. From 18 children younger of 10 years old with screening test (ID-PaGIA) positive for T. cruzi antibodies (Table 2) none had mother with positive serology for Chagas infection. The ages of the patients parasitologically positive are, respectively, 15, 23 and 59 years old.

Xenodiagnosis, hemoculture and PCR: From the 74 indirect xenodiagnosis of patients with positive screening serology, using 40 Triatoma infestans and/or Panstrongylus megistus nymphs of $3^{\text {rd }} / 4^{\text {th }}$ stage, only one (1.35\%) was positive for T. cruzi, while in the 98 hemocultures made in LIT medium, also only one (1\%) was positive. The polymerase chain reaction (PCR) done in 101 samples showed positive for three (2.97\%) of them. A single patient (23 years old) had xenodiagnosis, hemoculture and PCR positive and two other had only a PCR positive. The isolated strain was characterized as Z3 by analysis enzyme electrophoresis and also by typing mini-exon gene.

Clinical and electrocardiographic exam: The clinical and electrocardiographic exams that have been done in 106 patients with positive serology for Chagasic infection and in 87 negative controllers, who answered the invitation to come into the hospital, did not show any significant difference, neither any indication of morbidity for Chagas disease. Independently of positive or negative serology, it was observed eight cases of first degree right bundle branch block (4.1\%), seven cases of left ventricular overload (3.6\%), four cases of left anterior hemiblock (2\%) and some alterations of less importance, not related to heart pathology.

\section{DISCUSSION}

The high prevalence of sera positive reactions after screening tests (13.2\%), which was observed in the agglutination reactions with IDPaGIA Chagas Test, confirms previously observed results of $12.5 \%$ and $13.7 \%$, at the same area, with immunofluorescence ${ }^{14,19}$; this fact may be related to the presence of cross reactions with heterophile antibodies, EVI (anti-Gal) type, laminin and others, that may induce cross reactions with natural antibodies anti-T. cruzi (reviewed by BRENER, 1992 and STOLF, 1992) $)^{9,54}$; the cross reaction may be induced by diverse infections, including those caused by Leishmania sp and others kinetoplastida. Similarly, we have observed that, even in the case of ELISA reactions with purified (Biomanguinhos) and recombinant (CRA and FRA) T. cruzi antigens, it may occur cross reactions with sera from that region; possibly caused by the same mechanisms, previously mentioned. The ID-PaGIA Chagas Test ${ }^{\circledR}$ used as screening test for our lot or sera from Amazon, showed a very low specificity compared with results obtained by other authors $^{45}$ with lots of sera from traditional endemic areas for Chagas disease in Brazil.

Immunoblotting with trypomastigote excreted-secreted antigens (TESA-blot) of Trypanosoma cruzi carried out on 401 chagasic patients from different areas in Brazil, chronic, acute and congenital cases, and 111 non chagasic, included 30 cases of visceral and cutaneous leishmaniasis, showed a specificity index of 1,000 and no crossreactions ${ }^{56}$. In this survey we found three cases with positive PCR for $T$. cruzi $(2.97 \%)$, among the 101 analyzed, what leads us to infer that the prevalence of the infection by the parasite has, at least, the same level. Studies in progress using TESA-blot as confirmatory test for conventional serology for Chagasic infection, have indicate that the prevalence of the infection in our work area in the Amazon vary from $2 \%$ to $5 \%$, depending on the intensity of the contact of the population with sylvatic triatomines.

In this study, $20.7 \%$ of the interviewed persons recognized the triatomine; $60.7 \%$ of these, identified the Rhodnius brethesi as the "piaçava's lice" (Fig. 4), as they call this species of triatomine in that region. Besides, $30 \%$ of the individuals who identified the triatomine affirmed that they had already been bitten by the bug; what is a strong evidence of the risk of Chagasic infection vectorial transmission in that region, specially among individuals who gathers piaçava (Leopoldina piassaba) and their family members. We have confirmed this fact when we described the sylvatic triatomines' attack to human population, in that region ${ }^{15}$. In the other hand, despite of the serological reactions fragility due to the possibility of cross reactions, the fact that $25.8 \%$ of the individuals bitten by the triatomines presented positive serology against $11.7 \%$ of the not bitten ones - indicates a close association between contacting triatomine and positive serology.

The low morbidity of chagasic infection at the studied area, already indicated in previous work ${ }^{19}$ and confirmed in this one, may be related to the low rates of parasitemia, shown through xenodiagnosis, 


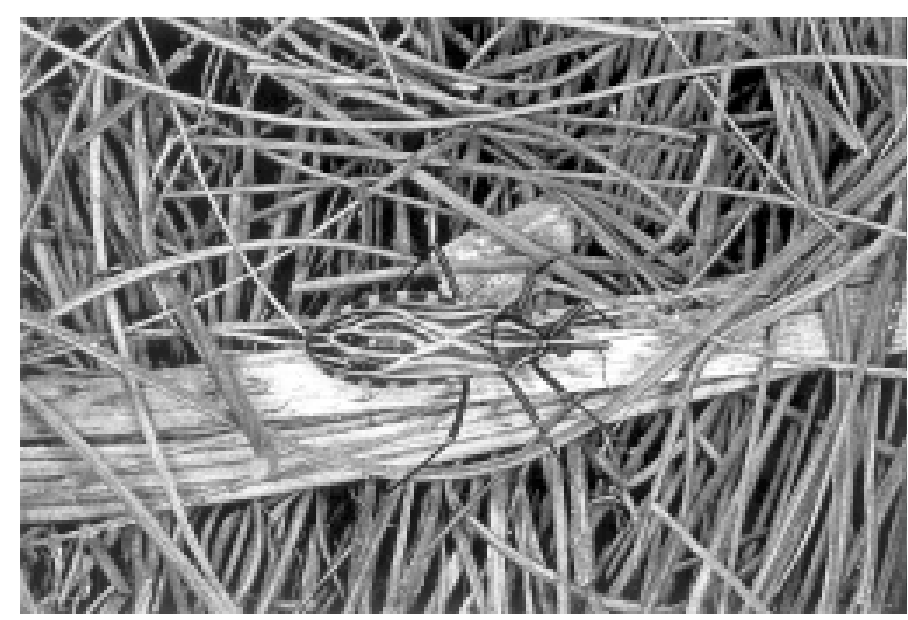

Fig. 4 - Piaçavas' fibers assembly with Rhodnius brethesi

hemoculture and PCR, or to the typical kind of parasite that circulates in the region. Recent studies developed by our group ${ }^{30,31}$, in collaboration with other ones, indicate intra/inter-specific differences between sylvatic strains of Trypanosoma cruzi typical of the region and domestic strain characteristic of endemic areas. Classified as T. cruzi I (sylvatic) and $T$. cruzi II (domestic), they may induce several antigenic stimuli and important morbidity differences, at least during disease's chronic phase, as demonstrated in previous works.

Chagas disease in the Brazilian Amazon represents a special chapter within the researches dedicated to this disease, and includes the etiological agents, reservoirs, vectors and, specially, the parasite-host relationship and the risks of disease endemization, which should be deeply studied. A new serological survey for Chagas disease in the Brazilian Amazon has been planned by the Ministry of Health to start in 2002. In addition, during the Fifth Meeting on Diagnostic, Treatment and Control of Tropical Diseases of the low Amazon it was proposed an agenda priorities for researches on Chagas disease in the Amazon region ${ }^{28}$.

\section{RESUMO}

\section{Doença de Chagas na Amazônia brasileira. IV. Um novo estudo seccional}

Um novo estudo de um conglomerado familiar de 194 domicílios com 996 pessoas residentes na cidade de Barcelos, Estado do Amazonas, foi feito a fim de re-avaliar o risco da doença de Chagas. Durante o inquérito as pessoas foram entrevistadas e nesta ocasião lhes foi mostrada uma coleção de Panstrongylus, Rodhnius e Triatoma, perguntando-lhes se reconheciam e se eventualmente tinham sido picados por aquele tipo de inseto. Nesta ocasião foi coletado 500 ul de sangue em tubos microtainer $^{\circledR}$ de 886 pessoas entrevistadas que deram permissão, após o consentimento informado. Um teste de triagem para anticorpos anti- $T$. cruzi foi realizado por um método de aglutinação de partículas de polímero colorido, sensibilizadas com três diferentes peptídeos sintéticos (ID-PaGIA Chagas Test ${ }^{\circledR}$, mostrou uma soropositividade de $13,2 \%$, mas somente $6,8 \%$ foram confirmados por imunofluorescência indireta e ELISA com antígenos de T. cruzi purificado. Duzentos e seis pessoas entrevistadas $(20,7 \%)$ reconheceram os triatomíneos como "piolho de piaçava" e 62 (30\%) confirmaram terem sido picados pelos insetos, $25,8 \%$ delas tiveram a sorologia de triagem positiva para infecção pelo T. cruzi. Alterações eletrocardiográficas foram verificadas em $9,3 \%$ dos soropositivos e em $11,9 \%$ dos negativos, o que foi considerado estatisticamente não significativo.

\section{ACKNOWLEDGEMENTS}

The present work was developed with resources of National Council for Scientific and Technological Development (Conselho Nacional de Desenvolvimento Científico e Tecnológico - CNPq), of National Health Foundation (Fundação Nacional de Saúde - FNS) and of Fiocruz Strategic Research Support Program (Programa de Apoio à Pesquisa Estratégica da Fiocruz - PAPES). It also received the contribution of students and technicians of the Tropical Medicine Department of Oswaldo Cruz Institute (Departamento de Medicina Tropical do Instituto Oswaldo Cruz - Fiocruz), in particular, Laura Cristina Santos, Maria Celeste Dias Spata and Julio Cesar Miguel, to whom we thank sincerely.

\section{REFERENCES}

1. ALMEIDA, F.B. - Triatomíneos da Amazônia. Encontro de três espécies naturalmente infectadas por Trypanosoma semelhante ao cruzi, no Estado do Amazonas (Hemiptera, Reduviidae). Acta amaz. (Manaus), 1: 89-93, 1971.

2. ALMEIDA, F.B. \& MACHADO, P.A. - Sôbre a infecção de Panstrongylus geniculatus pelo Trypanosoma cruzi em Manaus, Amazonas, Brasil. Acta amaz. (Manaus), 1: 71-75, 1971.

3. ARAGÃO, M.B. - Domiciliação de triatomíneos ou pré-adaptação à antropofilia e à ornitofilia? Rev. Saúde públ. (S. Paulo), 17: 51-55, 1983.

4. BARATA, J.M.S.; ROCHA, R.M.; RODRIGUES, V.L.C.C \& FERRAZ FILHO, N.A. Primeiro caso autóctone de tripanosomíase americana do Estado do Acre, Brasil e sua correlação com as cepas isoladas do caso humano e de triatomíneos silvestres da área. Rev. Saúde públ. (S. Paulo), 22: 401-410, 1988.

5. BARRET, T.V. \& GUERREIRO, J.C.H. - Os triatomíneos (Hemiptera, Reduviidae) em relação à doença de Chagas na Amazônia. In: VAL, A.L.; FIGIUOLO, R. \& FELDBERG, E. Bases científicas para estratégia de preservação e desenvolvimento da Amazônia: fatos e perspectivas. Manaus, Instituto Nacional de Pesquisas da Amazônia, 1991. p. 119-130.

6. BARRETO, M.P. - Reservatórios do Trypanosoma cruzi nas Américas. Rev. bras. Malar., 16: $527-552,1964$.

7. BARRETO, M.P. - Estudo sôbre reservatórios e vectores silvestres do Trypanosoma cruzi. XXII. Modificações dos focos naturais de tripanossomose americana e suas consequiências. Rev. soc. bras. Med. trop., 1: 167-173, 1967.

8. BRAZIL, R.P.; SILVA, A.R.; ALBARELLI, A. \& VALE, J.F. - Distribuição e infecção de triatomíneos por Trypanosoma do tipo cruzi na Ilha de São Luiz, Maranhão. Rev. soc. bras. Med. trop., 18: 257-260, 1985.

9. BRENER, Z. - Immuneresponse and immunopathology in T. cruzi infection. In: WENDEL, S.; BRENER, Z.; CAMARGO, M.E. \& RASSI, A., ed. Chagas disease (American Trypanosomiasis): its impact on transfusion and clinical medicine. São Paulo, ISBT; Brazil'92, 1992. p. 31-47.

10. CAMARGO, M.E.; SILVA, G.R.; CASTILHO, E.A. \& SILVEIRA, A.C. - Inquérito sorológico da prevalência da infecção chagásica no Brasil, 1975-1980. Rev. Inst. Med. trop. S. Paulo, 26: 192-204, 1984.

11. CHAGAS, C. - Infection naturelle des singes du Pará (Crysotrix sciureus) par Trypanosoma cruzi. C. R. Soc. Biol. (Paris), 90: 873, 1924. 
COURA, J.R.; JUNQUEIRA, A.C.V.; BÓIA, M.N.; FERNANDES, O.; BONFANTE, C.; CAMPOS, J.E.; SANTOS, L. \& DEVERA, R. - Chagas disease in the Brazilian Amazon. IV. A new cross-sectional study. Rev. Inst. Med. trop. S. Paulo, 44(3):159-165, 2002.

12. COURA, J.R. - Chagas'disease in the Brazilian Amazon: risk or hypothesis? Rev. Soc. bras. Med. trop., 23: 67-70, 1990.

13. COURA, J.R.; ARBOLEDA NARANJO, M. \& WILLCOX, H.P.F. - Doença de Chagas na Amazônia brasileira. Rev. Soc. bras. Med. trop., 26 (suppl. 2): 15-17, 1993.

14. COURA, J.R.; ARBOLEDA NARANJO, M. \& WILLCOX, H. P. F. - Chagas' disease in the Brazilian Amazon. II. A serological survey. Rev. Inst. Med. trop. S. Paulo, 37: 103-107, 1995.

15. COURA, J.R.; BARRETT, T.V. \& ARBOLEDA NARANJO, M. - Ataque de populações humanas por triatomíneos silvestres no Amazonas: uma nova forma de transmissão da infecção chagásica? Rev. Soc. bras. Med. trop., 27: 251-253, 1994.

16. COURA, J.R.; JUNQUEIRA, A.C.V.; BOIA, M.N. \& FERNANDES, O. - Chagas disease: from bush to huts and houses. Is it the case of the Brazilian Amazon? Mem. Inst. Oswaldo Cruz, 94 (suppl. 1): 379-384, 1999.

17. COURA, J.R.; JUNQUEIRA, A.C.V.; FERNANDES, O. et al. - Emerging Chagas disease in Amazonian Brazil. Trends Parasit., 18: 171-176, 2002.

18. COURA, J.R.; JUNQUEIRA, A.C.V.; GIORDANO, C.M. \& FUNATSU, R.K. - Chagas disease in the Brazilian Amazon. I. A. short review. Rev. Inst. Med. trop. S. Paulo, 36: 363-368, 1994.

19. COURA, J.R.; WILLCOX, H.P.F.; ARBOLEDA NARANJO, M.; FERNANDES, O. \& PAIVA. D.D. - Chagas disease in the Brazilian Amazon. III. A cross-sectional study. Rev. Inst. Med. trop. S. Paulo, 37: 415-420, 1995.

20. CRESCENTE, J.A.; VALENTE, S.A.S.;VALENTE, V.C. \& ARAÚJO, J.A. - Ocorrência de 4 casos agudos de doença de Chagas na Vila Icoaraci - PA. Rev. Soc. bras. Med. trop., 25 (suppl.): 29, 1992. (res. 062).

21. DEANE, L.M. - Tripanosomídeos de mamíferos da região Amazônica. I. Alguns flagelados encontrados no sangue dos mamíferos silvestres do estado do Pará. Rev. Inst. Med. trop. S. Paulo, 3: 15-28, 1961.

22. DEANE, L.M. - Animal reservoirs of Trypanosoma cruzi in Brazil. Rev. bras. Malar., 16: $27-48,1964$ a.

23. DEANE, L.M. - Tripanosomídeos de mamíferos da região Amazônica. III. Hemoscopia e xenodiagnóstico de animais silvestres dos arredores de Belém, Pará. Rev. Inst. Med. trop. S. Paulo, 6: 225-232, 1964b.

24. DEANE, L.M. - Tripanosomídeos de mamíferos da região Amazônica. IV. Hemoscopia e xenodiagnóstico de animais silvestres da estrada Belém-Brasília. Rev. Inst. Med. trop. S. Paulo, 9: 143-148, 1967

25. DEANE, L.M. \& DAMASCENO, R.G. - Tripanosomídeos de mamíferos da região Amazônica. II. Tripanosomas de macacos da zona do Salgado, Estado do Pará. Rev. Inst. Med. trop. S. Paulo, 3: 61-70, 1961.

26. DEANE, L.M. \& JANSEN, G. - Encontro do Schizotrypanum cruzi (Chagas, 1909) em marsupiais da espécie Marmosa cinerea Desmarest. Brasil-méd., 5: 265-266, 1939.

27. DEANE, M.P. \& DAMASCENO, R. - Encontro de Panstrongylus lignarius naturalmente infectado por Trypanosoma do tipo cruzi e algumas notas sobre a sua biologia. Rev. Serv. Saúde públ. (Rio de J.), 2: 809-814, 1949.

28. DIAS, J.C.P.; VINHAES, M.C.; SILVEIRA, A.C. et al. - Pesquisas prioritárias sobre doença de Chagas, agenda de curto e médio prazo. Rev. Soc. bras. Med. trop., 34: 497-498, 2001.

29. DOREA, R.C. - Doença de Chagas na Amazônia: aspectos epidemiológicos regionais e considerações a propósito de um caso pediátrico. Hiléia méd. (Belém), 3: 81-109, 1981.

30. FERNANDES, O.; SANTOS, S.S.; CUPOLILLO, E. et al. - A mini-exon multiplex polymerease chain reaction to distinguish the major groups of Trypanosoma cruzi and $T$. rangeli in the Brazilian Amazon. Trans. roy. Soc. trop. Med. Hyg., 95: 97-99, 2001.
31. FERNANDES, O.; SOUTO, R.P.; CASTRO, J.A. et al. - Brazilian isolates of Trypanosoma cruzi from humans and triatomines classified into two lineages using mini-exon and ribosomal RNA sequences. Amer. J. trop. Med. Hyg., 58: 807-811, 1998.

32. FERRARONI, J.J.; MELO, J.A.N. \& CAMARGO, M.E. - Moléstia de Chagas na Amazônia. Ocorrência de seis casos suspeitos, autóctones, sorologicamente positivos. Acta amaz. (Manaus), 7: 438-440, 1977.

33. FERREIRA. L.C. \& DEANE, L.M. - Novo depositário silvestre do Schizotrypanum cruzi (Chagas, 1909): a Irára, Toyra bárbara. Brasil-méd., 52: 1159-1161, 1938.

34. FORATTINI, O.P. - Biogeografia, origem e distribuição da domiciliação de triatomíneos no Brasil. Rev. Saúde publ. (S. Paulo), 14: 265-299, 1980.

35. FRAIHA NETO, H.; VALENTE, S.A.S.; VALENTE, V.C. \& PINTO A.Y.N. - Doença de Chagas endêmica na Amazônia? Rev. Acadêm. Med. (Pará), 6: 53-57, 1995.

36. FRANÇA, M.S.; FRADE, J.M.; KONASUGAWA, K. \& ALMEIDA, F.B. - Doença de Chagas: primeiro caso autóctone na Amazônia Ocidental, Amazonas, Brasil. Acta amaz. (Manaus), 10: 759-762, 1980.

37. LAINSON, R.; SHAW, J.J.; FRAIHA, H.; MILES, M.A. \& DRAPER, C.C. - Chagas' disease in the Amazon Basin. I. Trypanosoma cruzi in sylvatic mammals, triatomine bugs and man in the State of Pará, north Brazil. Trans. roy. Soc. trop. Med. Hyg., 73: 193-204, 1979.

38. LENT, H. \& WYGODZINSKY, P. - Revision of triatominaes (Hemiptera, Reduviidae) and their significance as vectors of Chagas' disease. Bull. Amer. Mus. nat. History, 163: (art. 3), 1979.

39. MASCARENHAS, B.M. - Triatomíneos da Amazônia: sobre o habitat e algumas considerações comportamentais de Rhodnius brethesi Matta, 1919 (Hemíptera Reduviidae: Triatominae) na Região do Médio Rio Negro, Amazonas. Bol. Mus. para. Emilio Goeldi, Serv. Zool., 7: 107-116, 1991.

40. MATTA, A. - Um novo reduvídeo do Amazonas. Rhodnius brethesi n. sp. Amazonas med. (Manaus), 2: 93-94, 1919.

41. MATTA, A. - Sobre o gênero Rhodnius do Amazonas. Amazonas med. (Manaus), 5: 161-162, 1922.

42. MILES, M.A.; SOUZA, A.A. \& PÓVOA, M. - Chagas' disease in the Amazon Basin. III. Ecotopes of ten triatomine bug species (Hemiptera, Reduviidae) from the vicinity of Belém, Pará State, Brazil. J. med. Entomol., 18: 266-278, 1981.

43. MILES, M.A.; ARIAS, J.R. \& SOUZA, A.A. - Chagas' disease in the Amazon Basin. V. Periurban palms as habitats of Rhodnius robustus and Rhodnius pictipes, triatominae vectors of Chagas' disease. Mem. Inst. Oswaldo Cruz, 78: 391-398, 1983.

44. PINTO, A.Y.N.; HARADA, G.B.; VALENTE, V.C. et al. - Acometimento cardíaco em pacientes com doença de Chagas aguda em microepidemia familiar, em Abaetuba, na Amazônia brasileira. Rev. Soc. bras. Med. trop., 34: 413-419, 2001

45. RABELLO, A.; LUQUETTI, A.O.; MOREIRA, E.F. et al. - Serodiagnosis of Trypanosoma cruzi infection using the new particle gel immunoassay - ID - PaGIA Chagas. Mem. Inst. Oswaldo Cruz, 94: 77-82, 1999.

46. REBELO, J.M.; BARROS, V.L.L. \& MENDES, W.A. - Espécies de triatominae (Hemiptera: Reduviidae) do Estado do Maranhão, Brasil. Cadern. Saúde públ. (Rio de J.), 14: 187-192, 1998

47. RODRIGUES, B.A. \& MELLO, G.B. - Contribuição ao estudo da tripanosomíase americana. Mem. Inst. Oswaldo Cruz, 37: 77-90, 1942.

48. RODRIGUES, I.C.; SOUZA, A.A.; TERCEROS, R. \& VALENTE, S. - Doença de Chagas na Amazônia. I. Registro de oito casos autóctones em Macapá. Rev. Soc. bras. Med. trop., 21: 193-197, 1988.

49. SHAW, J.; LAINSON, R. \& FRAIHA, H. - Considerações sobre a epidemiologia dos primeiros casos autóctones de doença de Chagas registrados em Belém, Pará, Brasil. Rev. Saúde públ. (S. Paulo), 3: 153-157, 1969. 

cross-sectional study. Rev. Inst. Med. trop. S. Paulo, 44(3):159-165, 2002.

50. SILVA, A.R.; MENDES, J.R.B.; MENDONÇA, M.L.; CUTRIM, R.N. \& BRAZIL, R.P - Primeiros casos agudos autóctones da doença de Chagas no Maranhão e inquérito soro-epidemiológico da população. Rev. Soc. bras. Med. trop., 18: 269-270, 1985.

51. SILVEIRA, A.C. \& PASSOS, A.D.C. - Altos índices de prevalência sorológica de infecção chagásica em área da Amazônia. Rev. Soc. bras. Med. trop., 19 (supl.): 45, 1986.

52. SILVEIRA, P.T.; DIAS, M.G.V.; PARDAL, P.P. et al. - Novo caso autóctone de doença de Chagas registrado no Estado do Pará, Brasil. Hiléia méd. (Belém), 1: 61-62, 1979.

53. SOUZA LIMA, M.Z.M.; MIRANDA SANTO, I.K.F.; SOUZA, A.A.A. et al. - Caso humano de infecção mista por Trypanosoma cruzi e organismos tipo Trypanosoma rangel procedente de Barcelos, Rio Negro, Amazonas. In: CONGRESSO DA SOCIEDADE BRASILEIRA DE MEDICINA TROPICAL, 21, São Paulo, 1985. Resumos. p. 44.

54. STOLF, A.M.S. - Trypanosoma cruzi antigens in serodiagnosis. In: WENDEL, S.; BRENER, Z.; CAMARGO, M.E. \& RASSI, A., ed. Chagas disease (American Trypanosomiasis): its impact on transfusion and clinical Medicine. São Paulo, ISBT; Brazil'92, 1992. p. 195-205.

55. TEIXEIRA, A.R.L.; MONTEIRO, O.S.; REBELO, J.M. et al. - Emerging Chagas disease: trophic network and cycle of transmission of Trypanosoma cruzi from palm trees in the Amazon. Emerg. infect. Dis., 7: 100-112, 2001.
56. UMEZAWA, E.S.; NASCIMENTO, M.S.; KESPER, J.R.N. et al. - Immunoblot assay using excreted-secreted antigens of Trypanosoma cruzi in serodiagnosis of congenital, acute, and chronic Chagas disease. J. clin. Microbiol, 34: 2143-2147, 1996.

57. VALENTE, S.A.S. \& VALENTE, V.C. - Situação atual da doença de Chagas na Amazônia Rev. Soc. bras. Med. trop., 26 (suppl. 2): 68-70, 1993.

58. VALENTE, S.A.S.; VALENTE, V.C.; FRAIHA NETO, H. - Considerations on the epidemiology and transmission of Chagas disease in the Brazilian Amazon. Mem. Inst. Oswaldo Cruz, 94 (suppl. 1): 395-398, 1999.

59. VALENTE, S.A.S.; VAlENTE, V.C.; PINTO, A.Y.N. \& FRAIHA NETO, H. Microepidemia familiar e transmissão oral da doença de Chagas na Amazônia brasileira. Mem. Inst. Oswaldo Cruz, 95 (suppl. 2): 69-72, 2000.

60. VALENTE, S.A.S.; VALENTE, V.C.; SILVA, F.M. et al. - Registro de doença de Chagas agudo em Sena Madureira, Estado do Acre. Rev. Soc. bras. Med. trop., 27 (suppl. 1): 169,1994

61. VALENTE, V.C.; VALENTE, S.A.S.; NOIREAU, F.; CARRASCO, H.J. \& MILES M.A. - Chagas disease in the Amazon Basin: association of Panstrongylus geniculatus (Hemiptera: Reduviidae) with domestic pigs. J. med. Entomol. , 35: 99-103, 1998.

Received: 28 January 2002

Accepted: 25 April 2002 